\title{
Effects of Surgical Excision and Radiation on Medulloblastoma Cell Invasiveness
}

\author{
Adrianna Ranger, Warren McDonald, Glenn S. Bauman, Rolando Del Maestro
}

\begin{abstract}
Objectives: Surgical resection and adjuvant radiation are mainstays of medulloblastoma (MB) patient management. We utilized a novel 3-dimensional assay to identify how (a) radiation, (b) excision of the primary tumour aggregate, and (c) both treatments combined influence MB cell invasiveness. Methods: Five MB cell lines (UW228-1, 2 and 3; Daoy, and Madsen) were implanted onto a 3-dimensional, type I collagen gel assay to assess tumour invasion distance over five days, in response to (1) needle-assisted excision of the central cell aggregate; (2) pre-exposure to single-dose and fractionated dose irradiation in doses from 6-25 and 8-24 Gy, respectively; and (3) excision plus either single-dose or fractionated radiation. Results: Within hours, individual MB cells detached from the surface of the cell aggregates and invaded the collagen matrix, to distances up to $1200 \mu \mathrm{m}$ and at rates up to $300 \mu \mathrm{m}$ daily. The UW228-1 cell line was less invasive than the other cell lines and was dropped from further analysis. In the four remaining lines, a dosedependent decline in tumour invasiveness was identified, both for single-dose and fractionated radiation, which achieved statistically decreased invasion distances at higher doses, especially of fractionated irradiation. Excision of the central tumour aggregate tended towards exerting a late effect on cell invasion, but exerted no significant influence on the radio-sensitivity of residual cells. Conclusions: Both single-dose and fractionated dose irradiation appear to inhibit MB cell invasiveness in a dose-dependent manner, whereas excision of the central cell aggregate exerts no effect on residual invading cells.
\end{abstract}

RÉSUMÉ: Effets de l'excision chirurgicale et de l'irradiation sur le caractère envahissant du médulloblastome. Objectifs : La résection chirurgicale et la radiothérapie sont le traitement de base du médulloblastome (MB). Nous avons utilisé une nouvelle méthode d'analyse tridimensionnelle pour identifier comment l'irradiation, l'excision de la tumeur primaire et les deux traitements combinés influencent le caractère envahissant des cellules du MB. Méthodes : Cinq lignées cellulaires de MB (UW228-1, 2, 3, Daoy et Madsen) ont été implantées dans un gel de collagène de type I tridimensionnel pour évaluer la distance d'invasion de la tumeur en 5 jours en réponse à : 1) une excision de l'agrégat cellulaire central au moyen d'une aiguille ; 2) une pré-exposition à une dose unique et à des doses fractionnées de radiation de 6-25 et 8-24 Gy respectivement ; et 3) une excision et soit une dose unique ou fractionnée de radiation. Résultats : En quelques heures des cellules individuelles se sont détachées de la surface des agrégats cellulaires et ont envahi la matrice de collagène à une distance pouvant atteindre $1200 \mu$ m et à une vitesse pouvant atteindre 300 $\mu \mathrm{m}$ par jour. La lignée cellulaire UW228-1 était moins envahissante que les autres et nous l'avons exclue des études subséquentes. Chez les quatre autres lignées cellulaires, un déclin du caractère envahissant de la tumeur qui était proportionnel à la dose administrée a été observé, tant pour la dose unique que pour les doses fractionnées de radiation, avec une diminution significative des distances d'invasion pour les doses plus élevées, surtout pour l'irradiation fractionnée. L'excision de la partie centrale de l'agrégat tumoral avait tendance à exercer un effet tardif sur le caractère envahissant des cellules, mais n'avait pas d'influence significative sur la radiosensibilité des cellules résiduelles. Conclusions : L'irradiation par dose unique ou fractionnée semble inhiber le caractère envahissant des cellules de MB de façon proportionnelle à la dose administrée alors que l'excision du centre de l'agrégat cellulaire ne produit pas d'effet sur les cellules envahissantes résiduelles.

Can. J. Neurol. Sci. 2009; 36: 631-637

In children, brain cancers can be particularly devastating; and medulloblastoma (MB), a primitive tumour of neuroectodermal origin, is among the most common. Rare in adults ${ }^{1-5}$, these tumours generally account for between 20 and $40 \%$ of paediatric intracranial malignancies worldwide ${ }^{6-12}$, and have an incidence of approximately 1-7 per million, depending upon the population studied and how medulloblastoma and the base populations are defined $^{11,13-16}$. They are especially common among preschoolers $^{17,18}$, even among infants who are less than 18 months-of-age ${ }^{19,20}$. Outcomes in paediatric medulloblastoma patients, relative to those with most other childhood malignancies, tend to be poor, with five-year survival rates in several series less than $50 \% \%^{6,10,14,16,21,22}$. One likely reason for the generally poor prognosis associated with these tumours is that

\footnotetext{
From the Brain Research Laboratories, Experimental Research Unit, Division of Neurosurgery (AR, WM); London Regional Cancer Program- Radiation Oncology, Victoria Hospital (GSB), London Health Sciences Centre, London, Ontario; Brain Tumor Research Centre, Montreal Neurological Institute and Hospital (RDM), Montreal, Quebec, Canada.

Received January 20, 2009. Final Revisions Submitted May 25, 2009. Correspondence to: Adrianna Ranger, Division of Neurosurgery, Children's Hospital London Health Sciences Centre, 800 Commissioners Road East, Room E6-315, London, Ontario, N6A 4G5, Canada.
} 
they are highly invasive, exhibiting a well-known propensity for leptomeningeal dissemination ${ }^{23-25}$, and the ability to establish multiple deposits that are quite distant from the site of the original tumour ${ }^{23-25}$. The predominant site for disease recurrence is in the posterior fossa, due to the presence of residual cells which have invaded surrounding normal structures. Curative surgical excision of recurrent tumour rarely is possible, so that adjuvant therapies are required. However, for a variety of reasons that include chemo-resistance and the blood-brain barrier, currently utilized chemotherapy regimens sometimes have relatively little therapeutic effect. Consequently, radiation therapy is the mainstay of initial adjuvant treatment, and may be used in disease recurrence. Unfortunately, normal brain, and especially the young brain, is highly sensitive to radiation therapy, so that the long-term sequelae of brain cancer treatment include progressively reduced intellect and other immediate and long-term cognitive and central neurological deficits ${ }^{26-33}$. It is for this reason that attempts must be made to find ways both (1) to reduce the inherent invasiveness of these tumours, and (2) to enhance their responsiveness to adjuvant irradiation.

It was for the specific purpose of studying medulloblastoma cell invasiveness that we created a specific, 3-dimensional medulloblastoma model. This model was generated via the implantation of individual tumour aggregates, derived from different medulloblastoma cell lines, into a collagen type I gel, thereby forming a semi-solid matrix at $37^{\circ} \mathrm{C}$. In this model, following implantation, individual cells detach from the surface of the cell aggregates to invade the surrounding matrix. The process of tumour invasion can be monitored under various conditions, and it can be quantified. The advantage of this system over monolayer systems for studying invasive behaviour is the maintenance of complex tumour architecture in vitro. For the current study, we utilized this novel 3-dimensional assay to investigate the invasive properties of five human medulloblastoma cell lines and their sensitivity to both surgical excision of the main tumour aggregate and radiation. Our specific objectives were (1) to obtain quantitative data on the invasiveness and doubling times of medulloblastoma cell lines within the model; and (2) to identify how (a) radiation, (b) excision of the primary tumour aggregate, and (c) a combination of radiation and aggregate excision, influence the invasiveness of these cells. Our ultimate objective is to be able to identify promoters of medulloblastoma radio-sensitivity that might be useful in actual clinical practise.

\section{Materials And Methods}

\section{Cell Lines}

Five established medulloblastoma cell lines (UW 228-1, 2282, 228-3, Daoy, and Madsen) were grown in a monolayer culture using standard tissue culture techniques. The three cell lines UW 228-1, -2 and -3 - were provided generously by Dr. John R. Silber, from the University of Washington, in Seattle; these lines were derived from a single patient and exhibit features consistent with neuronal differentiation ${ }^{34}$. Daoy, a glial cell-differentiated, GFAP positive cell line, was obtained from the American Tissue Culture Collection (ATCC HTB; Rockville, Md.) at passage 3. The Madsen cell line, at passage 1, was provided as the kind gift of Dr. Richard Youle at the National Institutes of Health, in Washington, D.C. These five lines were selected for their proven ability to grow in a monolayer culture; and, although none will grow as spheroids, they all readily generate tumour aggregates, using the methods described below.

\section{Cell Cultures}

The five established human medulloblastoma cell lines detailed above were grown as monolayer cultures in Dulbecco's Modified Eagle's Medium (DMEM; GIBCO BRL, Burlington, Ontario, Canada), supplemented with $10 \%$ foetal calf serum (Bioproducts Inc., U.S.A.), penicillin, streptomycin and fungizone (Whittaker Products, Walkersville, MD) at $37^{\circ} \mathrm{C}$ in a humidified atmosphere of $5 \% \mathrm{CO}_{2}$ and $95 \%$ air (UW series) and $9 \% \mathrm{CO}_{2}$ and $91 \%$ air (Daoy and Madsen lines). While cells were growing in monolayer culture, the medium was changed every three days.

\section{Collagen Matrix Preparation}

Collagen type I gel (Vitrogen 100, purchased from Collagen Corporation, Fremont CA) was combined with 10-fold concentrated DMEM containing phenol red. The $\mathrm{pH}$ was adjusted via the addition of $0.1 \mathrm{M} \mathrm{NaOH}$. A final collagen concentration of $2.4 \mathrm{mg} / \mathrm{ml}$ was used, having been identified in a previous study as the optimal concentration for monitoring cell invasion $^{35}$. Five hundred $\mu 1$ of this solution was added to individual wells in NUNC 4 well plates. Single tumour cell aggregates were implanted into each well, which then were allowed to gel at $37^{\circ} \mathrm{C}$. The gels then were overlaid with DMEM and $5 \%$ foetal calf serum, after which cellular invasion was monitored, as described below.

\section{Cell Aggregate Preparation}

All cell lines were plated onto $60 \mathrm{MM}$ NUNC tissue culture plates. Once confluence was achieved in the monolayer, cell aggregates of approximately $1000 \mu \mathrm{m}$ in diameter were produced by means of a Falcon cell scraper. The aggregates then were implanted into NUNC 4 well plates containing liquid collagen type I gel, as described above.

\section{Monitoring Cell Invasion}

In most instances, within hours of implantation, individual cells had detached visibly from the surface of the tumour cell aggregate and invaded the surrounding matrix (Figure 1). Previous observations utilizing a similar model ${ }^{35}$ had demonstrated that invasiveness tends to plateau over a period of five days. Consequently, we restricted our observations for invasiveness to five days post-implantation. An inverted microscope fitted with a micrometer eyepiece was used to evaluate daily invasion distance, measured as the distance in $\mu \mathrm{m}$ from the edge of the tumour aggregate to the population of cells which had invaded the furthest distance from that aggregate.

Each day, a Nikon model camera, mounted onto the inverted microscope, was used to photograph the tumour aggregates that were embedded within the gels, using Kodak Tech Pan film.

\section{Excision of the Central Tumour Mass}

Following implantation into the collagen matrix, tumour cells were allowed to invade for a 72-hour period, at which time the central mass of cells was excised from the gel using an 18-gauge 


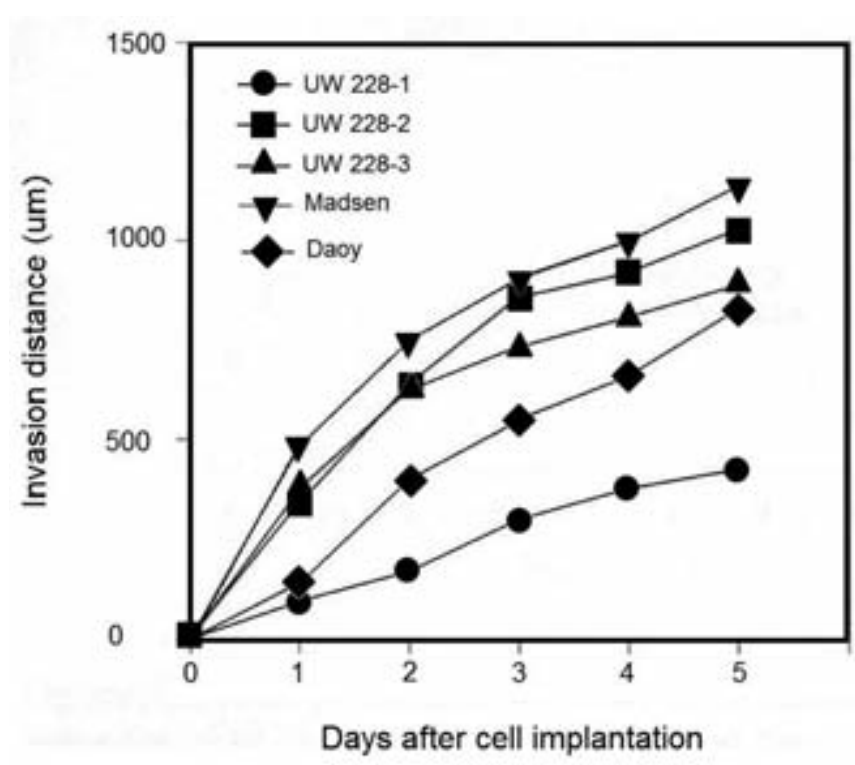

Figure 1: Medulloblastoma cell line invasion into the collagen gel.

sterile needle and a dissecting microscope, leaving behind the population of cells which had clearly invaded the matrix. Invasion rates and total distances were assessed for the remainder of the seven-day period, for four determinations per cell line.

\section{Radiation Treatments}

Twenty-four hours after implantation, cell lines were treated with either single or fractionated doses of radiation using an Eldorado Co-60 irradiator at a single dose of $200 \mathrm{cGy} / \mathrm{min}$ to total doses of $25 \mathrm{~Gy}$ (single doses) or $24 \mathrm{~Gy}$ (fractionated doses, over four days). Control gels containing tumour aggregates from each cell line received no radiation. Radiation also was delivered to gels from which the main tumour mass had been excised 24 hours previously, to determine the effect that irradiation might have on a surgically-treated model. Once again, four replicates were performed per cell line.

\section{Statistical analysis}

As stated above, a total of four replicates were conducted for each cell line per experiment, from which means and standard deviations were calculated. Student's t tests were used to compare means between treatment (excision; radiation; excision + radiation) and control conditions for each cell line and, as appropriate, for each dose of radiation administered, with all tests 2-tailed. To adjust for multiple comparisons, because we used four cell lines and nine doses of radiation (five single doses and four fractionated doses), a Bonferroni-adjusted $\mathrm{p}$ value of 0.001 ( 0.05 divided by 36 ; [ 4 x 9]) was used as the threshold for statistical significance.

\section{RESULTS}

\section{Medulloblastoma Invasion into a Collagen Type I Gel Matrix}

Within hours of implantation, individual cells readily detached from the surface of the cell aggregates and invaded the collagen matrix, to distances of up to $1200 \mu \mathrm{m}$ and at rates of up to $300 \mu \mathrm{m}$ per day (Figure 1). The three-dimensional nature of the collagen matrix and the morphology of the invading cell phenotype were demonstrated by scanning electron microscopy (Figure 2). These invasive patterns, produced by cells migrating away from the main cell mass, generally assumed the appearance of a 'halo' or 'sunburst' for all cell lines; but dissimilarities in the various cell lines were apparent in both the morphology and the behaviour of the invasive phenotype. The UW 228-3 cell line was especially unique, in that a loop of invading cells was observed consistently, associated with one side of the main cell mass. In all cases, individual cells that were observed at the invading margin appeared to display either an elongated, bipolar morphology or a more rounded configuration.

Overall, however, the main differences between the various cell lines were their maximal invasion distances and their doubling times (Table). With respect to the former, average invasion rates ranged from a low of $93+/-9 \mu \mathrm{m} /$ day for the UW 228-1 cell line, to a high of $235+/-5 \mu \mathrm{m} /$ day for UW 228-2. Among the cell lines derived from the same patient, UW 228-1 exhibited very little invasive capacity, having invaded the gels less than $500 \mu \mathrm{m}$ at five days. Conversely, all of the other cell lines rapidly invaded the gels to distances of up to $1175 \mu \mathrm{m}$, and at rates of $167-235 \mu \mathrm{m}$ per day. Meanwhile, doubling times ranged from a low of $33.7+/-0.4$ hours (more rapid doubling) for the Daoy cell line, to a high of $62.5+/-4.2$ hours (slower doubling) for the Madsen line, with the doubling times for all

Table: Proportional effect of single-dose and fractionated dose radiation on medulloblastoma cell invasion distance: comparisons versus baseline

\begin{tabular}{|c|c|c|c|c|c|c|c|c|}
\hline \multirow[b]{2}{*}{ Cell line } & \multicolumn{4}{|c|}{ Single Dose Radiation } & \multicolumn{4}{|c|}{ Fractionated Dose Radiation } \\
\hline & $\begin{array}{l}\text { Radiation } \\
\text { Dose } \\
\end{array}$ & Net difference & $\%$ reduction & $p$ value & \begin{tabular}{|l}
$\begin{array}{l}\text { Radiation } \\
\text { Dose }\end{array}$ \\
\end{tabular} & \begin{tabular}{|l|}
$\begin{array}{l}\text { Net } \\
\text { difference }\end{array}$ \\
\end{tabular} & $\%$ reduction & $p$ value \\
\hline UW $228-2$ & $\begin{array}{l}6 \mathrm{~Gy} \\
9 \mathrm{~Gy} \\
12 \mathrm{~Gy} \\
18 \mathrm{~Gy} \\
25 \mathrm{~Gy} \\
\end{array}$ & $\begin{array}{l}+16 \\
-243 \\
-406 \\
-374 \\
-359 \\
\end{array}$ & $\begin{array}{l}-2 \% \\
24 \% \\
40 \% \\
36 \% \\
35 \% \\
\end{array}$ & $\begin{array}{l}0.075 \\
0.034 \\
0.107 \\
0.015 \\
0.003 \\
\end{array}$ & $\begin{array}{l}8 \mathrm{~Gy} \\
12 \mathrm{~Gy} \\
16 \mathrm{~Gy} \\
24 \mathrm{~Gy}\end{array}$ & $\begin{array}{l}-168 \\
-606 \\
-773 \\
-799 \\
- \\
\end{array}$ & $\begin{array}{l}9 \% \\
31 \% \\
39 \% \\
41 \%\end{array}$ & $\begin{array}{l}0.222 \\
0.005 \\
<0.001 \\
<0.001\end{array}$ \\
\hline UW $228-3$ & $\begin{array}{l}6 \mathrm{~Gy} \\
9 \mathrm{~Gy} \\
12 \mathrm{~Gy} \\
18 \mathrm{~Gy} \\
25 \mathrm{~Gy} \\
\end{array}$ & $\begin{array}{l}-1 \\
-109 \\
-250 \\
-328 \\
-508 \\
\end{array}$ & $\begin{array}{l}0 \% \\
12 \% \\
28 \% \\
37 \% \\
57 \% \\
\end{array}$ & $\begin{array}{l}0.855 \\
0.095 \\
<0.001 \\
0.002 \\
0.022 \\
\end{array}$ & $\begin{array}{l}8 \mathrm{~Gy} \\
12 \mathrm{~Gy} \\
16 \mathrm{~Gy} \\
24 \mathrm{~Gy}\end{array}$ & $\begin{array}{l}-688 \\
-656 \\
-573 \\
-500 \\
- \\
\end{array}$ & $\begin{array}{l}42 \% \\
40 \% \\
35 \% \\
30 \%\end{array}$ & $\begin{array}{l}0.016 \\
0.006 \\
0.037 \\
0.028 \\
-\end{array}$ \\
\hline Madsen & $\begin{array}{l}6 \mathrm{~Gy} \\
9 \mathrm{~Gy} \\
12 \mathrm{~Gy} \\
18 \mathrm{~Gy} \\
25 \mathrm{~Gy}\end{array}$ & $\begin{array}{l}+80 \\
-31 \\
-191 \\
-235 \\
-336 \\
\end{array}$ & $\begin{array}{l}-7 \% \\
3 \% \\
17 \% \\
21 \% \\
29 \% \\
\end{array}$ & $\begin{array}{l}0.406 \\
0.787 \\
0.085 \\
0.039 \\
0.004 \\
\end{array}$ & $\begin{array}{l}8 \mathrm{~Gy} \\
12 \mathrm{~Gy} \\
16 \mathrm{~Gy} \\
24 \mathrm{~Gy} \\
-\end{array}$ & $\begin{array}{l}-350 \\
-500 \\
-560 \\
-830 \\
- \\
\end{array}$ & $\begin{array}{l}19 \% \\
27 \% \\
30 \% \\
45 \%\end{array}$ & $\begin{array}{l}0.007 \\
0.013 \\
<0.001 \\
<0.001 \\
-\end{array}$ \\
\hline Daoy & $\begin{array}{l}6 \mathrm{~Gy} \\
9 \mathrm{~Gy} \\
12 \mathrm{~Gy} \\
18 \mathrm{~Gy} \\
25 \mathrm{~Gy}\end{array}$ & $\begin{array}{l}+36 \\
-33 \\
-77 \\
-170 \\
-225\end{array}$ & $\begin{array}{l}-4 \% \\
4 \% \\
9 \% \\
20 \% \\
27 \%\end{array}$ & $\begin{array}{l}0.618 \\
0.671 \\
0.147 \\
0.032 \\
0.002\end{array}$ & $\begin{array}{l}8 \mathrm{~Gy} \\
12 \mathrm{~Gy} \\
16 \mathrm{~Gy} \\
24 \mathrm{~Gy} \\
-\end{array}$ & $\begin{array}{l}-368 \\
-553 \\
-663 \\
-862 \\
-\end{array}$ & $\begin{array}{l}20 \% \\
30 \% \\
36 \% \\
47 \% \\
-\end{array}$ & $\begin{array}{l}0.121 \\
0.015 \\
0.003 \\
<\mathbf{0 . 0 0 1} \\
-\end{array}$ \\
\hline
\end{tabular}




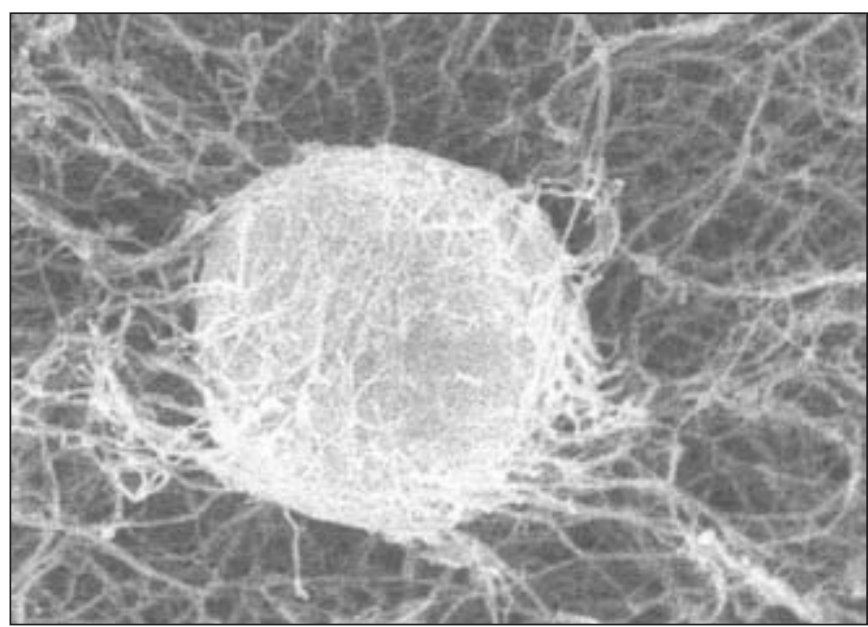

Figure 2: Scanning electron micrograph demonstrating medulloblastoma cell invasion into a collagen matrix.

three UW 228 lines virtually identical, ranging from 42.0 to 42.8 hours. Although no formal correlation analysis was performed, upon graphical representation, cell line invasion rates did not appear to correlate with cell line doubling time.

Because the UW228-1 cell line clearly was less invasive than all four other lines, it was excluded from all subsequent analyses.

\section{Influence of Surgical Incision on Invasive Behaviour}

Surgical incision of the main tumour mass in the collagen type I model was carried out without difficulty. It was easy to visualize the residual invading cells and monitor their movement. No significant difference was identified between the untouched (control) cells versus the residual cells for which the central tumour aggregate had been excised, in terms of total invasion distance over the first two days. However, as shown in Figure 3, which depicts results obtained for experiments involving the Madsen cell line, for both the control and excised conditions, tumour invasion progressed at a rapid, steady rate over the first two to three days; but then, as invasion started to decline, the decline appeared more dramatic in the absence of the central cell aggregate. Across all cell lines, this difference was not statistically significant, but a graphic trend was observed.

\section{Influence of Radiation on Invasive Behaviour}

After 6 Gy of single dose irradiation, and for all cell lines, there was no apparent decrease and, if anything, a nonstatistically significant slight increase in cell invasiveness; thereafter, however, with single doses ranging from 9 Gy to 25 Gy, there generally was a dose-dependent decrease in tumour invasion distance (Table, Figure 4). Relative to baseline, this achieved a Bonferroni-adjusted level of significance only for the UW228-3 cell line at a dose of 12 Gy, though statistical significance $(\mathrm{p}<0.005)$ was approached at the highest doses $(18$ and/or $25 \mathrm{~Gy}$ ) for all cell lines.

With fractionated dose radiation, there was an immediate decline in cell invasiveness, even at the lowest dose of radiation

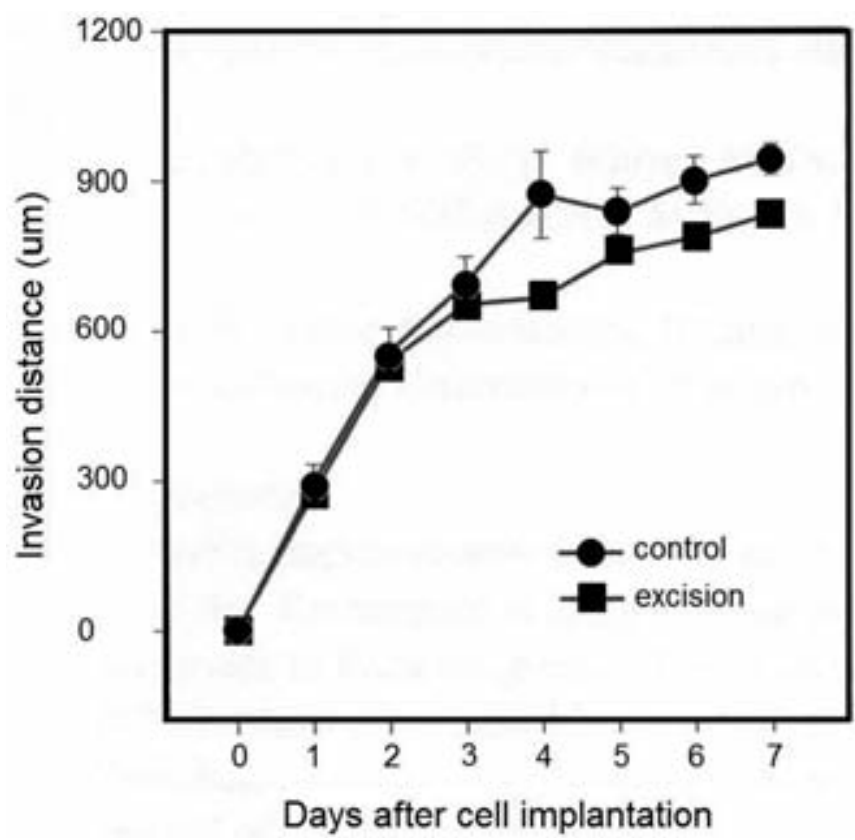

Figure 3: Effect of surgical excision of the main tumour aggregate on the invasive behaviour of Madsen, a representative medulloblastoma cell line.

given (8 Gy), with a Bonferroni-adjusted level of statistically significant decline achieved at doses as low as 12 Gy for the UW228-2 and Madsen lines, and at 18 Gy for the Daoy cell line, but not for UW228-3 cells (Figure 5). As with single-dose radiation, there was a graphically-apparent trend towards declining invasiveness for all cell lines.

\section{Influence of Radiation after Surgical Excision}

Comparing irradiated cells versus cells that were irradiated after excision of the central tumour cell aggregate, there was no detectable influence of surgical incision on the radio-sensitivity of the residual invasive cells (data not shown).

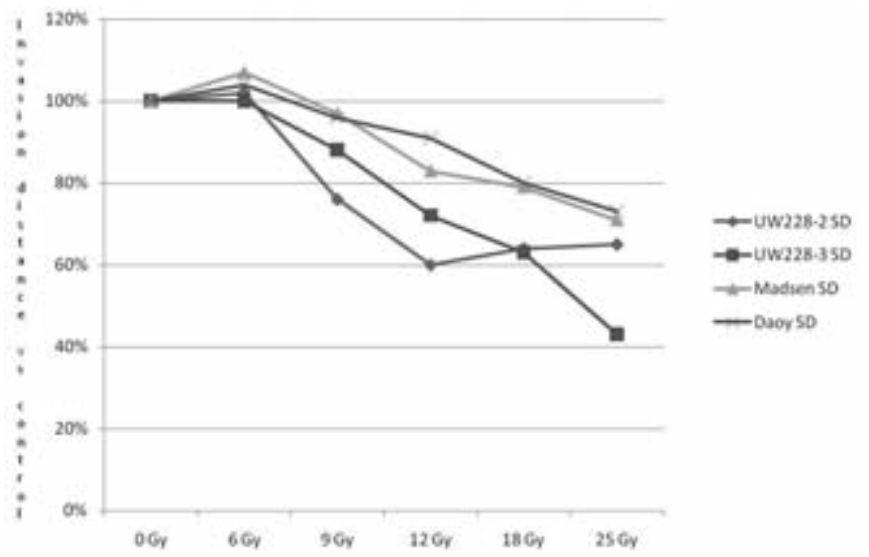

Figure 4: Effect of single-dose (SD) irradiation on medulloblastoma invasion distance. 


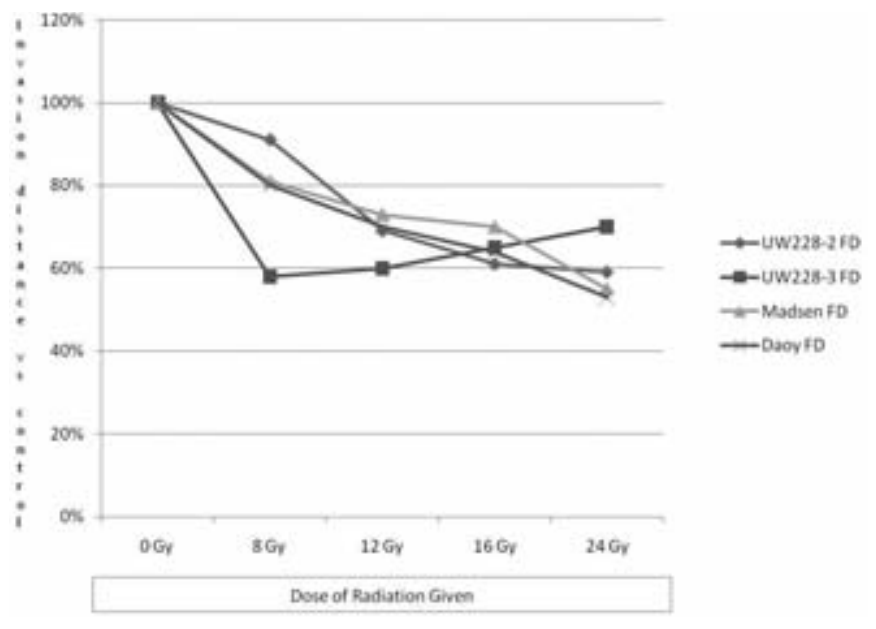

Figure 5: Effect of fractionated-dose (FD) irradiation on medulloblastoma invasion distance.

\section{DISCUSSION}

Medulloblastomas are among the most lethal tumours in children, both because of their intracranial location and their high degree of invasiveness, one of the major predictors of poor outcome being leptomeningeal spread ${ }^{36}$. Because of the way in which tumour cells invade surrounding normal brain, their dissemination via the cerebrospinal fluid ${ }^{37}$, and their resultant spread distant to the site of the initial tumour, complete surgical resection often is not feasible. Also, chemotherapy often is ineffective, both because medulloblastoma cells tend to be chemo-resistant and because of the blood-brain barrier, so that a combination of surgical de-bulking and diffuse axial radiation usually is required ${ }^{37}$. Unfortunately, progressively reduced intellect and other cognitive and central neurological deficits ${ }^{26-33}$ are a none too uncommon consequence of this treatment combination, especially in the young developing brain. These consequences even include alterations in the sleep-wake cycle that persist long into adulthood, up to 30 years post-treatment, including the requirement for almost one full hour more of sleep per day ${ }^{38}$; and the frequent formation of gross anatomical defects, like cavernomas and cavernous angiomas, that occasionally require later surgical excision due to seizures, bleeding and other problems ${ }^{39-41}$. Some evidence exists that reduced dose radiotherapy may lessen the risk and extent of adverse effects ${ }^{42}$. However, under-dosing of radiation increases the risk of tumour recurrence and a resultant increase in mortality ${ }^{37}$. In addition, even though McMillan et $\mathrm{al}^{43}$ demonstrated in 1993 that medulloblastomas are very radiosensitive, invading cells seem to be relatively resistant. This has prompted a few research teams to investigate ways by which to predict and/or increase the radio-sensitivity of these tumours $^{44-47}$. In general these studies have demonstrated (1) that different cell lines differ in their degree of radio-sensitivity ${ }^{48-50}$; and (2) that cell radio-sensitivity can, in fact, be altered by a variety of external means ${ }^{45,47}$.
For example, Blazek et $\mathrm{al}^{49}$ sought to characterize the radiobiological properties induced by the surface marker, CD133, on medulloblastoma cells from two cell lines, Daoy and D283, and found that CD133+ Daoy cells are relatively radioresistant. Salaroli et al ${ }^{44}$ studied the gamma-radiation response of two MB cell lines, both from a cellular and molecular point of view, and discovered that a p53 wild-type cell line was more sensitive to ionizing radiation than a p53 mutated line. And Tsuboi et $a l^{50}$ isolated two mutant clones from a single medulloblastoma, one radiosensitive (OS-3) and one resistant (OR-5), but also found that the administration of $5 \mathrm{mM}$ of caffeine generated greater cytotoxicity in the latter cells.

Meanwhile, Ozawa et $\mathrm{al}^{47}$ investigated the cytotoxicity induced by sodium phenylacetate (NaPA), both alone and in combination with exposure to X-rays, in two medulloblastoma cell lines, Masden and Daoy, as well as in SF-767 human glioblastoma cells. Pre-exposure of all three cell lines to relatively low concentrations of NaPA for up to five days failed to enhance radio-sensitivity; but enhanced radio-sensitivity was achieved when either oxic or hypoxic cells were exposed to higher drug concentrations (> 50-70 $\mathrm{mM}$ ) for one hour immediately prior to irradiation. The authors cautioned that central nervous system toxicity could be a problem in vivo, due to the inherent toxicity of high serum concentrations of NaPA, so that developing local drug-delivery strategies to achieve adequate drug concentrations at the specific tumour site remains a priority of future research. Most recently, Lee et $\mathrm{al}^{45}$ have demonstrated the anti-proliferative and radio-sensitizing effects of caffeic acid phenethyl ester, an active component of propolis, on MB cells of the Daoy cell line, and that these effects are achievable by various mechanisms, like depleting glutathione, increasing ROS activity, and inhibiting NF-kappaB activity. To date, however, attempts to augment the effects of radiation therapy, either in the lab or during clinical treatment of medulloblastoma, remain in their infancy, with the combination of chemotherapy and radiation perhaps doing greater harm than $\operatorname{good}^{30}$.

For purposes of studying the invasiveness of medulloblastoma in vitro, we have created a specific, 3-dimensional medulloblastoma model, similar to models that already have been developed for astrocytomas ${ }^{35}$, generated via the implantation of individual tumour aggregates, derived from different medulloblastoma cell lines, into a collagen type I gel, thereby forming a semi-solid matrix at $37^{\circ} \mathrm{C}$. As previously stated, because individual cells rapidly detach from the surface of the cell aggregates in the gel to invade the surrounding matrix, tumour invasion can be monitored and quantified, the advantage over monolayer systems being that our model maintains the tumour's general architecture. In the current study, we utilized this novel 3-dimensional assay primarily to identify how (a) radiation, (b) excision of the primary tumour aggregate, and (c) a combination of radiation and aggregate excision influence the invasiveness of various medulloblastoma cell lines. We demonstrated that tumour invasion is decreased in a dosedependent manner by both single and fractionated doses of radiation, though the latter may be more effective overall. This dose-dependent effect was apparent among all cell lines, though to a greater or lesser extent. Excision of the central tumour aggregate had no observable influence on the radio-sensitivity of 
the invading cells; however, it did tend towards decreasing the invasiveness of the cells after the first two to three days in the absence of radiation. The reason for this we only can conjecture, but it likely relates to the release of invasion mediators by the centrally aggregated cells.

Clearly, further research is necessary, to validate the use of this 3-dimensional model, to verify the radio-sensitivity of these and other medulloblastoma cell lines. We utilized five lines, but many others have been identified ${ }^{51-57}$, and the level of tumour aggressiveness and overall patient outcomes appear to be significantly affected by the immunohistochemical properties of the tumour itself. For example, whereas Pfister et al determined that the addition of either $6 \mathrm{q}$ or $17 \mathrm{q}$ and genomic amplification of MYC or MYCN were associated with poor outcomes, all patients with $6 \mathrm{q}$-deleted tumors survived ${ }^{51}$. Similarly, Mendrzyk et $\mathrm{al}^{55}$ reported that gains at $17 \mathrm{q} 23.2$-qter, and losses at $17 \mathrm{p} 13.1$ to $17 \mathrm{p} 13.3$, and over-expression of CDK6 were significantly correlated with poor outcomes.

For the same reasons, it also will be important to study the mechanisms behind the apparent eventual inhibitory effect of surgical excision of the primary tumour aggregate using lines with different immunohistochemical characteristics. Nonetheless, we feel that this model can be of use in the in vitro study of medulloblastoma; and that it may be of use in the study of ways by which to positively alter the effects of various types of radiation on tumour death, growth and invasiveness. In addition, to date, it is unclear why invading MB cells seem more resistant to radiation than those within the central tumour aggregate; one hypothesis is that invading cells remain in the Go phase of the cell cycle, contrary to the rapidly dividing cells in the central tumour, but this remains unproven. Ultimately, we hope that clarification of these issues will translate into improved treatment of tumours in clinical practise, thereby enhancing survival and diminishing the untoward effects of high-dose radiation therapy on the young, developing brain of children.

\section{ACKNOWLEDGEMENTS}

The authors thank Dr. John R. Silber of the University of Washington, in Seattle, and Dr. Richard Youle of the National Institutes of Health, in Washington, D.C for kindly providing us with four of the five cell lines used in this research; and Dr. William Stetler-Stevenson, of the Center for Cancer Research, Bethesda MD, for providing us with MMP-1 and -2 .

\section{REFERENCES}

1. Ang C, Hauerstock D, Guiot MC, Kasymjanova G, Roberge D, Kavan $\mathrm{P}$, et al. Characteristics and outcomes of medulloblastoma in adults. Pediatr Blood Cancer. 2008; 51:603-7.

2. Coulbois S, Civit T, Grignon Y, Taillandier L, Girard F, Marchal C, et al. [Adult medulloblastoma. Review of 22 patients] [Article in French]. Neurochirurgie. 2001; 47:6-12.

3. Giordana MT, Schiffer P, Lanotte M, Girardi P, Chio A. Epidemiology of adult medulloblastoma. Int J Cancer. 1999; 80: 689-92.

4. Farwell JR, Flannery JT. Adult occurrence of medulloblastoma. Acta Neurochir (Wien). 1987; 86:1-5.

5. Pobereskin L, Treip C. Adult medulloblastoma. J Neurol Neurosurg Psychiatry. 1986; 49:39-42.

6. Chan MY, Teo WY, Seow WT, Tan AM. Epidemiology, management and treatment outcome of medulloblastoma in Singapore. Ann Acad Med Singapore. 2007; 36:314-8.
7. Kadri H, Mawla AA, Murad L. Incidence of childhood brain tumors in Syria (1993-2002). Pediatr Neurosurg. 2005; 41:173-7.

8. Feltbower RG, Picton S, Bridges LR, Crooks DA, Glaser AW, McKinney PA. Epidemiology of central nervous system tumors in children and young adults (0-29 years), Yorkshire, United Kingdom. Pediatr Hematol Oncol. 2004; 21:647-60.

9. Lang O, Kondas O, Torok S, Hauser P, Bognar L, Schuler D. [Incidence of pediatric brain tumors in Hungary between 1989 and 1999] [Article in Hungarian]. Orv Hetil. 2002; 143:451-4.

10. Agerlin N, Gjerris F, Brincker H, Haase J, Laursen H, Moller KA, et al. Childhood medulloblastoma in Denmark 1960-1984. A population-based retrospective study. Childs Nerv Syst. 1999; 15:29-36 (discussion 37).

11. Stiller CA, Bunch KJ. Brain and spinal tumours in children aged under two years: incidence and survival in Britain, 1971-85. Br J Cancer. 1992; 18:S50-3.

12. Chi JG, Khang SK. Central nervous system tumors among Koreans-a statistical study on 697 cases. J Korean Med Sci. 1989; 4: 77-90.

13. Alston RD, Newton R, Kelsey A, Newbould MJ, Birch JM, Lawson B, et al. Childhood medulloblastoma in northwest England 1954 to 1997: incidence and survival. Dev Med Child Neurol. 2003; 45:308-14.

14. McNeil DE, Coté TR, Clegg L, Rorke LB. Incidence and trends in pediatric malignancies medulloblastoma/primitive neuroectodermal tumor: a SEER update. Surveillance Epidemiology and End Results. Med Pediatr Oncol. 2002; 39:190-4.

15. Farinotti M, Ferrarini M, Solari A, Filippini G. Incidence and survival of childhood CNS tumours in the Region of Lombardy, Italy. Brain. 1998; 121:1429-36.

16. Roberts RO, Lynch CF, Jones MP, Hart MN. Medulloblastoma: a population-based study of 532 cases. J Neuropathol Exp Neurol. 1991; 50:134-44.

17. Kopac S, Jereb B. Medulloblastoma in children 0-3 years old: forty years' experience in Slovenia. Pediatr Hematol Oncol. 2004; 21:17-21.

18. Rickert $\mathrm{CH}$. Epidemiological features of brain tumors in the first 3 years of life. Childs Nerv Syst. 1998; 14:547-50.

19. Kumar R, Tekkok IH, Jones RA. Intracranial tumours in the first 18 months of life. Childs Nerv Syst. 1990; 6:371-4.

20. Janish W, Haas JF, Schreiber D, Gerlach H. Primary central nervous system tumors in stillborns and infants. Epidemiological considerations. J Neurooncol. 1984; 2:113-6.

21. Johannesen TB, Langmark F, Lote K. Cause of death and long-term survival in patients with neuro-epithelial brain tumours: a population-based study. Eur J Cancer. 2003; 39:2355-63.

22. Di Rocco C, Iannelli A, Papacci F, Tamburrini G. Prognosis of medulloblastoma in infants. Childs Nerv Syst. 1997; 13:388-96.

23. Koeller KK, Rushing EJ. From the archives of the AFIP: medulloblastoma: a comprehensive review with radiologicpathologic correlation. Radiographics. 2003; 23:13-37.

24. Ayan I, Kebudi R, Bayindir C, Darendeliler E. Microscopic local leptomeningeal invasion at diagnosis of medulloblastoma. Int $\mathrm{J}$ Radiat Oncol Biol Phys. 1997; 39:461-6.

25. Laerum OD. Local spread of malignant neuroepithelial tumors. Acta Neurochir (Wien). 1997; 139:515-22.

26. Mulhern RK, Merchant TE, Gajjar A, Reddick WE, Kun LE. Late neurocognitive sequelae in survivors of brain tumours in childhood. Lancet Oncol. 2004; 5:399-408.

27. Palmer SL, Reddick WE, Gajjar A. Understanding the cognitive impact on children who are treated for medulloblastoma. J Pediatr Psychol. 2007; 32:1040-9.

28. Spiegler BJ, Bouffet E, Greenberg ML, Rutka JT, Mabbott DJ. Change in neurocognitive functioning after treatment with cranial radiation in childhood. J Clin Oncol. 2004; 22:706-13.

29. Qiu D, Kwong DL, Chan GC, Leung LH, Khong PL. Diffusion tensor magnetic resonance imaging finding of discrepant fractional anisotropy between the frontal and parietal lobes after whole-brain irradiation in childhood medulloblastoma survivors: reflection of regional white matter radiosensitivity? Int J Radiat Oncol Biol Phys. 2007; 69:846-51. 
30. Abd El-Aal HH, Mokhtar MM, Habib EE, El-Kashef AT, Fahmy ES. Medulloblastoma: conventional radiation therapy in comparison to chemo radiation therapy in the post-operative treatment of high-risk patients. J Egypt Natl Canc Inst. 2005; 17: 301-7.

31. Maddrey AM, Bergeron JA, Lombardo ER, McDonald NK, Mulne AF, Barenberg PD, et al. Neuropsychological performance and quality of life of 10 year survivors of childhood medulloblastoma. J Neurooncol. 2005; 72:245-53.

32. Murthy SN, Cohen ME. Pseudomigraine with prolonged aphasia in a child with cranial irradiation for medulloblastoma. J Child Neurol. 2002; 17:134-8.

33. Walter AW, Mulhern RK, Gajjar A, Heideman RL, Reardon D, Sanford RA, et al. Survival and neurodevelopmental outcome of young children with medulloblastoma at St Jude Children's Research Hospital. J Clin Oncol. 1999; 17:3720-8.

34. Keles GE, Berger MS, Srinivasin J, Kolstoe DD, Bobola MS, Silber JR. Establishment and characterization of four human medulloblastoma-derived cell lines. Oncol Res. 1995; 7: 493-503.

35. Tamaki M, McDonald W, Amberger V, Moore E, DelMaestro R. Implantation of C6 astrocytoma cells into collagen type I gels: invasive, proliferative and enzymatic characterizations. J Neurosurg. 1997; 87:602-9.

36. Paulino AC, Cha DT, Barker JL Jr, Lo S, Manera RB. Patterns of failure in relation to radiotherapy fields in supratentorial primitive neuroectodermal tumor. Int J Radiat Oncol Biol Phys. 2004; 58:1171-6

37. Halperin EC. Impact of radiation technique upon the outcome of treatment for medulloblastoma. Int J Radiat Oncol Biol Phys. 1996; 36:233-9.

38. Van Someren EJ, Swart-Heikens J, Endert E, Bisschop PH, Swaab DF, Bakker PJ, et al. Long-term effects of cranial irradiation for childhood malignancy on sleep in adulthood. Eur J Endocrinol. 2004; 150:503-10.

39. Lew SM, Morgan JN, Psaty E, Lefton DR, Allen JC, Abbott R. Cumulative incidence of radiation-induced cavernomas in longterm survivors of medulloblastoma. J Neurosurg. 2006; 104: 103-7.

40. Lee JK, Cherlvarajah R, King A, David KM. Rare presentations of delayed radiation injury: a lobar hematoma and a cystic spaceoccupying lesion appearing more than 15 years after cranial radiotherapy: report of two cases. Neurosurgery. 2004; 54: 1010-3 (discussion 1014).

41. Baumgartner JE, Ater JL, Ha CS, Kuttesch JF, Leeds NE, Fuller $\mathrm{GN}$, et al. Pathologically proven cavernous angiomas of the brain following radiation therapy for pediatric brain tumors. Pediatr Neurosurg. 2003; 39:201-7.

42. Reddick WE, Russell JM, Glass JO, Xiong X, Mulhern RK, Langston JW, et al. Subtle white matter volume differences in children treated for medulloblastoma with conventional or reduced dose craniospinal irradiation. Magn Reson Imaging. $2000 ; 18: 787-93$

43. McMillan TJ. In vitro radiosensitivity of human medulloblastoma cell lines. J Neurooncol. 1993; 15:91-2.
44. Salaroli R, Di Tomaso T, Ronchi A, Ceccarelli C, Cammelli S, Cappellini A, et al. Radiobiologic response of medulloblastoma cell lines: involvement of beta-catenin? J Neurooncol. 2008; 90 : 243-51.

45. Lee YY, Kao CL, Tsai PH, Tsai TH, Chiou SH, Wu WF, et al. Caffeic acid phenethyl ester preferentially enhanced radiosensitizing and increased oxidative stress in medulloblastoma cell line. Childs Nerv Syst. 2008; 24:987-94.

46. Meyer JJ, Marks LB, Halperin EC, Kirkpatrick JP. Kinetic modeling of tumor growth and dissemination in the craniospinal axis: implications for craniospinal irradiation. Radiat Oncol. 2006; $1: 48$

47. Ozawa T, Lu RM, Hu LJ, Lamborn KR, Prados MD, Deen DF. Radiopotentiation of human brain tumor cells by sodium phenylacetate. Cancer Lett. 1999; 142:139-46.

48. Powell SN, McMillan TJ, Steel GG. In vitro radiosensitivity of human medulloblastoma cell lines. J Neurooncol. 1993; 15:91-2.

49. Blazek ER, Foutch JL, Maki G. Daoy medulloblastoma cells that express CD133 are radioresistant relative to CD133- cells, and the CD133+ sector is enlarged by hypoxia. Int J Radiat Oncol Biol Phys. 2007; 67:1-5.

50. Tsuboi K, Tsuchida Y, Endo K, Yoshii Y, Nose T. Isolation of radiosensitive and radioresistant mutants from a medulloblastoma cell line. Brain Tumor Pathol. 1997; 14:19-25.

51. Pfister S, Remke M, Benner A, Mendryzk F, Toedt G, Felsberg J, et al. Outcome prediction in pediatric medulloblastoma based on DNA copy-number aberrations of chromosomes $6 q$ and $17 q$ and the MYC and MYCN loci. J Clin Oncol. 2009; 27:1627-36.

52. de Haas T, Hasselt N, Troost D, Caron H, Popovic M, ZadravecZaletel L, et al. Molecular risk stratification of medulloblastoma patients based on immunohistochemical analysis of MYC, LDHB, and CCNB1 expression. Clin Cancer Res. 2008; 14: 4154-60.

53. Sanson M, Laigle-Donadey F, Benouaich-Amiel A. Molecular changes in brain tumors: prognostic and therapeutic impact. Curr Opin Oncol. 2006; 18:623-30.

54. Min HS, Lee YJ, Park K, Cho BK, Park SH. Medulloblastoma: histopathologic and molecular markers of anaplasia and biologic behavior. Acta Neuropathol. 2006; 112:13-20.

55. Mendryzk F, Radlwimmer B, Joos S, Kokocinski F, Benner A, Strange DE, et al. Genomic and protein expression profiling identifies CDK6 as novel independent prognostic marker in medulloblastoma. J Clin Oncol. 2005; 23:8853-62.

56. Eberhart CG, Kratz J, Wang Y, Summers K, Stearns D, Cohen K, et al. Histopathological and molecular prognostic markers in medulloblastoma: c-myc, N-myc, TrkC, and anaplasia. J Neuropathol Exp Neurol. 2004; 63:441-9.

57. Neben K, Korshunov A, Benner A, Wrobel G, Hahn M, Kokocinski $\mathrm{F}$, et al. Microarray-based screening for molecular markers in medulloblastoma revealed STK15 as independent predictor for survival. Cancer Res. 2004; 64:3103-11. 